\title{
THE HOLOCAUST AND HIROSHIMA. MORAL OTHERNESS AND MORAL FAILURE IN WAR
}

\begin{abstract}
The 20th century was an age of extremes. In this article I concentrate on two disasters, the Holocaust and Hiroshima, in order to develop a philosophical reading of moral extremes under circumstances of war. My aim is to differentiate between these two events by exposing a normative framework. The significance of the Holocaust points to the phaenomenon of a rupture of species, which stands for a moral transgression never thought of. In analytical terms, this confronts us with the clashing of two normative orders: Firstly, the universal moral respect of every human being; secondly, the radical particularism of Nazism. To denounce the moral otherness of the latter is to highlight the war aims of Nazism: imperial aggression to dominate Europe, and annihilation of the Jews as a world-historical mission. In view of both aims, war against Nazism was just. The moral disaster of Hiroshima, however, stands in marked contrast to this characterization. The political leaders of the US did not intend to annihilate the Japanese people; they thought they would end war by making use of a nuclear weapon. It is, therefore, a misleading metaphor to speak of a "nuclear holocaust", or to allude to a genocidal action in this case. This does not mean at all that dropping the bomb was justified. Quite contrary to the US official stance, it is important to consider this event in moral terms by relying on precise historical circumstances and well-founded critical analysis. There is strong evidence that it was a moral failure to opt for the bomb. This comes close to the diagnosis of a war crime within a just war framework. Nevertheless, this diagnosis must be kept distinct from the type of crime involved in the Holocaust.
\end{abstract}

Keywords: Holocaust, Hiroshima, moral otherness, war crimes, political responsibility

1. The Holocaust: a rupture of species. 2. War, annihilation policy, and moral otherness.

3. Hiroshima: war and moral failure.

In 2015 we not only commemorate the genius of Paulus Vladimiri, but also reflect on an age of extremes seventy years after World War II. I'm going to discuss two exceptional disasters of this age, the Holocaust and Hiroshima, in order to develop a philosophical reading of moral extremes under the circumstances of war. My aim 
is to differentiate between these two events by exposing a normative framework relating moral philosophy to hard historical questions.

Firstly, I shall qualify the moral dimension of the Holocaust. Secondly, I shall formulate my interpretation by analyzing the combined strategy of waging war and annihilation implemented by Nazism. I shall argue that we are confronted here with the clashing of two normative orders in war: Western universalism and Nazi particularism. War against the latter was just. Thirdly, I shall consider the atomic disaster of Hiroshima, which must be discussed as a question of political responsibility. I shall argue that in this case we are confronted with a severe moral failure, a war crime within a just war framework.

\section{THE HOLOCAUST: A RUPTURE OF SPECIES}

The moral dimension of the Holocaust leads to a seemingly paradoxical diagnosis. The extermination of the Jews was carried out under normative premises that give rise to an alternative morality or a moral otherness of its own. Such a statement needs a terminological clarification. One can speak of moralities in descriptive terms as a way to analyse them without accepting their moral content. In this sense, Nazi morality can be analyzed without having to accept it normatively. Additionally, I use the term "ethics" to refer to moral philosophy and the terms "morals" or "moralities" to refer to the general domain of reflection on ethics. ${ }^{1}$

The pivotal features of Nazism were its characterization of the Jews as a collective body and its permanent struggle against the "Jewish enemy". Nazism denied Jewish people the right to existence and in so doing abandoned the path of the moral unity of the human

1 To speak in descripitve terms of a morality of National Socialism is widely accepted for methodological reasons. Cf. for a broad and recent discussion: W. Bialas, Moralische Ordnungen des Nationalsozialismus, Göttingen 2014. 
species. Mankind no longer comprised all human beings, but it was split into those who were 'real' humans and those who were not. Nazism established a new order of values under its world view ("Weltanschaunng"), a key element of which was the dogma of a Jewish conspiracy to dominate the world as set forth in the "Protocols of the Elders of Zion".

Albeit a forgery, this "document" was considered absolutely authentic by the Nazis. They developed an enmity toward the Jews as a homogeneous body incorporating certain essential qualities as a people or race in stark contrast to the Aryan-German people's community ("Volksgemeinschaft"). The Jews were accused of obstructing the mission of the Aryan-German race to advance its creative and idealistic potential and to dispute the historical principle of a never-ending struggle between races. The attribution of negative racial qualities comes close to seeing the Jews as a spiritual race, responsible for a universalistic picture of man formed during the French Revolution under the idea of equality.

This is the reason why the Nazis' fight against the Jews was a struggle against a universalistic self-image of man. The radicalism of this type of anti-Semitism provided the leading motive for the Holocaust. This does not rule out other motives, but the existential enmity toward an alleged threat of a collective Jewish predominance over the world constitutes the framework of anti-Jewish activities and operations at any level.

I propose the term "rupture of species" (“Gattungsbruch") to characterize the radicalism of Nazism in moral terms. ${ }^{3}$ This expression is meant to signify the overthrowing of traditional moral

2 Cf. B. W. Segel, A Lie and a Libel. The History of the Protocols of the Elders of Zion, ed. by R.S. Levy, Lincoln 1995.

3 It is noteworthy that my term was adopted by Feliks Tych in his speech before the German parliament in January, 27, 2010: http://www.bundestag.de/kulturundgeschichte/ geschichte/tych/rede/248106. Cf. for further argument: R. Zimmermann, Philosophie nach Auschwitz, Reinbek bei Hamburg 2005, Ch. 1. 
limits in order to drive mankind into a new world of moral otherness. ${ }^{4}$ In the long run, however, it was not only the "Jewish" idea of human equality that was destined to be abolished. Heinrich Himmler, leader of the SS, denounced Christianity as an enemy comparable to the Jews. ${ }^{5}$ Additionally, the road to moral otherness was interwoven with the utopian project of founding man anew ("neues Menschentum"). Moral change as induced by Nazism implied the moral transformation of mankind as a whole. Historical research teaches us that the Nazi project was able to generate support at all levels of German society and abroad. It was no illusion to conceive of a substantial moral transformation and to expect a broad solidarity in this attempt.

The SS and its organizations were an exemplary community of moral transformation. In our context it is important to remember that the SS represents not only the highest type of a Nazi community with respect to a militant combination of ideology and racial struggle. This community also delivered the elitist paradigm of ideal Nazi socialization and moral transformation, which could serve as an educational model for the whole society. Ideal virtues such as loyalty, obedience, honor and comradeship were conceived in direct relation to Adolf Hitler and the personification of those concepts culminated in every SS-man's oath of allegiance to Hitler to their death. This development shows the suspension of the concept of conscience in the Christian tradition, which was open to individual moral reflection. As a result, the breaking of moral limits was continuously encouraged. ${ }^{6}$

4 For a similar account of the moral significance of the term, see: E.L. Fackenheim, To Mend the World. Foundations of Future Jewish Thought, New York 1982, 250: "The continuity is broken, and thought, if it is not itself to be and remain broken, requires a new departure and a new category (...) because the Holocaust is not a relapse into 'barbarism', a 'phase in a historical dialectic', a radical-but-merely-'parochial' catastrophe. It is a total rupture." The denial of a common humanity by Nazism is clearly described in: A. Margalit, G. Motzkin, The Uniqueness of the Holocaust, Philosophy \& Public Affairs 25(1995)1, 65-83.

5 Cf. P. Longerich, Heinrich Himmler: A Life, Oxford 2011, Ch. III.

6 Cf. B. Wegner, The Waffen-SS. Its Ideology, Organization and Function, Oxford 1990. Cf. also: C. Koonz, The Nazi Conscience, Cambridge/MA, London 2003. 
If we take historical experience seriously, we must admit that the Nazi movement was a by-product of the European social, cultural, and political conditions at that time. The bewilderment caused by the Holocaust and other moral catastrophes concerns the actions of people like ourselves. As Yehuda Bauer says: “(...) the tragedy of the Shoah was not its inhumanity but the fact that the Nazis were humans, just as we are." ${ }^{\prime}$ Since we are dealing with moral considerations, it is especially important not to exclude the protagonists, supporters and perpetrators of National Socialism from a broad domain of normality, however sharply their ideology and moral convictions may be criticized. We must accept the open range of human possibilities and take a realistic view of history, which presents us with human developments with very different outcomes. ${ }^{8}$

My concept of the rupture of species is not vulnerable to the consideration that Nazism does not contest that Jews are human beings. Although this is in one sense correct, it is wrong in a different and more relevant sense of 'mankind'. We have to account for an ambiguity in the concept of mankind. On the one hand, "mankind" is used as a descriptive term of ordinary language and refers to the global features of individuals, groups, peoples, nations and religious communities as a whole. In this sense, Jews are part of mankind. On the other hand, however, "mankind" stands for "true mankind" ("wahres Menschentum"), which is a normatively limited concept not at all compatible with the common facts of mankind. In this sense,

7 Y. Bauer, Einige Überlegungen zur Shoah, (my translation), Zeitschrift für Geschichtswissenschaft 54(2006)6, 547. Cf. P. J. Haas, Morality after Auschwitz. The Radical Challenge of the Nazi Ethic, Philadelphia 1988, 232: "Although the Holocaust is unique in its awfulness, it is a firm part of normal human history (...) In studying the Holocaust, we study not only a particular society of the past but ourselves as well."

8 Cf. I. Clendinnen, Reading the Holocaust, Cambridge 1999, $111 \mathrm{f}$.: "I do not pretend that 'understanding' men like Hitler, or Himmler, or Stangl is an easy matter. I would only insist that the problem is not qualitatively different from the problem inherent in understanding any other human beings - and that our understanding of our fellow human beings will not be and cannot be complete." 
the Jews are not part of mankind but must be eliminated to achieve a purified kind of mankind. This normatively restricted concept is the counterpart of the rupture of species. Hannah Arendt made this clear when she concluded her report on the Eichmann trial with a critique of the Nazi hubris as an entitlement to decide who should live and who should not. ${ }^{9}$

Saul Friedländer's work on the persecution and extermination of the Jews by Nazism is particularly suited to support my analysis with two important sets of considerations. First, he takes issue with the historian Dan Diner for using the term "rupture of civilization" as an epistemic concept to show the bewilderment of the Jews at the "counter-rationality" of the Nazis. The Jewish victims, according to Diner, could not understand the motives and actions of the extermination project because this was going against the Nazis' own economic interests and priorities in the conduct of war. Diner ascribes a cognitive incoherence to the Nazis because they shifted their focus away from purposive rationality and self-preservation, which is selfevident in the tradition of Western civilization. The Nazis, therefore, did not simply act irrationally. They embraced a counter-rationality that defeated the hope of some Jewish leaders that they might survive along with their community by working efficiently for the Nazi system.

In Friedländer's view, however, this account is not necessary because of the dominant trait of the Nazi-Jewish enmity characterized above. He emphasizes the decisive point that "the entire murder system stemmed from a single postulate: The Jews were an active threat, for all of Aryan humanity in the long run, and in the immediate future for a Reich embroiled in a world war. Thus the Jews had

9 Cf. H. Arendt, Eichmann in Jerusalem: A Report on the Banality of Evil, New York 1994, Epilogue. I leave aside the many discussions on Arendt's concepts of radical evil or banality of evil. My concept of a rupture of species, which has as a counterpart in the diagnosis of a failure of species-commitment, avoids the complications of Arendt's concepts. 
to be exterminated before they could harm »Fortress Europe« from within or join forces with the enemy coalition they had themselves set against the Reich. ${ }^{10}$ It follows that the dilatory tactics of the Jewish leaders during the extermination phase could not possibly succeed because the Germans were not disposed to take "any »interests« into account".

The fatal logic of all this can, to my mind, be summarized by saying that there was no "counter-rationality" involved in Nazism. Rather, we find a far-reaching counter-morality responsible for shaping a new model of the world. Rupture of species as a moral term is, therefore, needed to cope with the moral dimension in question.

This is confirmed by contemporary German-Jewish debates. In a speech delivered to the Knesset (2008), the German chancellor Angela Merkel used the term "rupture in civilization" in a moral sense when she acknowledged German responsibility for the "moral catastrophe" of the Shoah. It seems clear that there is an intention to articulate the Shoah in a moral vocabulary adequate to the moral significance of this epochal event. For the sake of clarity, rupture of species adequately refers to the moral significance of the Holocaust.

The second important suggestion made by Friedländer consists in his thesis that the central focus of Nazism's radical anti-Semitism was a "redemptive anti-Semitism"11 aimed at "liberating" the AryanGerman community and the whole of mankind from the Jews. The moral transformation I have characterized enables us to speak similarly of a morality of redemption. The religious meaning of "redemption" is turned into a mundane project. There is no longer an otherworldly redemption: the Last Judgment takes place in history.

10 S. Friedländer, Nazi Germany and the Jews, Vol. II: The Years of Extermination, New York 2007, 557.

11 S. Friedländer, Nazi Germany and the Jews, Vol. I: The Years of Persecution 1933-1939, New York 1997, Part I, Ch. 3. 
The shocking historical experiences of Nazism and the Holocaust lay bare in a very general sense the opposition that existed between a Nazi morality of redemption and a type of morality we might call a morality of integration. Moral integration presumes that every human being is a part of the human species and a member of mankind simply by her or his existence. A morality of integration can also be ascribed in an elementary sense to a hierarchical or otherwise traditional society, which denies equal rights to all humans but holds it to be self-evident that every human is an integral part of mankind. To be clear, moral norms inaugurated by world religions should also be placed under the heading of a morality of integration. To take Christian morality as an example, it is clear that every human being is part of the human world whereas "redemption" is not of this world but otherworldly in a realm of transcendent salvation.

On the basis of these distinctions it becomes obvious that the specific morality of integration developed in the Western world since the eighteenth century as a universalism of the equality of man and equal rights for all men, stands in fundamental opposition to Nazi morals, which must be considered as forms of a radical particularism.

Additionally, however, it should become evident that historical experience points to a plurality of divergent moralities that cannot be unified. The morality of Bolshevism is another notable example that would require an account of its own. ${ }^{12}$ At the level of metaethics, therefore, we should acknowledge a moral pluralism in history. The idea of a moral monism, strongly represented in the Kantian tradition, dissolves after a systematic reflection on moral history. In other words, the universalism of human equality and human rights has to be seen as historical universalism, which is itself a historical innovation without a conceptual guarantee.

12 Cf. R. Zimmermann, National Socialism - Bolshevism - Universalism, in: Nazi Ideology and Ethics, eds. W. Bialas, L. Fritze, Cambridge 2014, 391-422. 
This points to a further issue that I can only mention in passing here. For our purposes, it will suffice to characterize my conception against the background of Richard Rorty's critique of an objectivist or transcendentalist version of universalism. I do agree with Rorty's critique, but I deny the suspension of the language of universalism in favour of what Rorty calls the "ethnocentricity" of universalism and human rights. ${ }^{13}$ One can share with Rorty the historical approach, particularly with respect to the significance of historical experience and research, and at the same time preserve universalism in terms of the moral content of a historically situated morality open to worldwide acceptance. Such acceptance is not secured in advance and may be threatened in the future. It is therefore possible to speak consistently of the universalization of egalitarian universalism by taking the latter as a moral content. In this sense, universalism is conceived as historical universalism in a universe of divergent moral orders. I shall defend this approach below in my analysis of the opposition between egalitarian universalism and Nazism.

\section{WAR, ANNIHILATION POLICY, AND MORAL OTHERNESS}

An intimate connection between Nazi morality, war and annihilation policy is shown by the fact that the Nazi project to exterminate the Jews was pursued under a growing pressure on military operations and against the considerable strength of the anti-Nazi coalition, not least after the entry of the United States into the war.

This sheds light on the interconnection between waging war in order to dominate Europe and the conspiracy theory pertaining to the Jewish dominance of the world. Of course, the war of aggression

13 R. Rorty, Contingency, Irony, and Solidarity, Cambridge 1989, Ch. 3. Idem, Truth and Progress, Cambridge 1998, Ch. 2. Occasionally Rorty reduces his "ethnocentric particularism" to a denial of an objectivist universalism. This is compatible with my historical reading of universalism. 
against Poland in 1939 and the extension of war aims throughout the world had their own pecularities and repercussions that would affect a broad range of power politics. To take notice of this dimension of the war is to recall the so-called Generalplan Ost, which concerned the enslavement of Slavic peoples and the mass killings of non-Jewish civilians. $^{14}$

However, the so-called "Jewish question" and the fight against the "Jewish-capitalist-bolshevist world conspiracy" (the Soviet Union and Germany became enemies in 1941) were still the primary aims of the Nazi offensive. The strategy of the Generalplan Ost was designed to go hand in hand with the fight against the Jews. Albeit the mass killings of Slavic peoples were not organized to exterminate them entirely, it would be wrong to think of a hierarchy of victims. Murder is murder. That doesn't prevent, however, the recognition that the Jewish case runs even deeper in its normative significance.

In January 1939 Hitler anticipated war in a speech in which he declared the international finance Jewry responsible for a possible war. In 1940 Himmler favored the so-called Madagascar project to establish a ghetto for millions of Jews in Madagascar. Once again, this project highlights the interconnection of the war waging strategy with the suppression of the Jews: one important aspect of the project was to use the ghetto to exert pressure on the U.S. and prevent their entry into the war. The project failed and the Nazi radicalization took other forms. Among them were the ruthless mass murders of Jews and Slavic populations during the war, as well as the establishing of Jewish ghettos in Eastern Europe, not least the Warsaw Ghetto, in order to exert repressive control over the entire Jewish population. The episodes of violence against the Jews continued in concentration camps and in death camps.

14 This episode is extensively described in: T. Snyder, Bloodlands. Europe between Hitler and Stalin, New York 2010. 
This sketchy overview may suffice to characterize the annihilation policy implemented by Nazism in the context of the war. All these developments were driven by the belief in a never-ending struggle between races and the necessity of the Aryan-German dominance over the world. The breakdown of this perspective in the course of the war left the annihilation policy as the sole war aim achievable by Nazism.

The moral-political opposition of egalitarian universalism and Nazi particularism can be summarized in the following way:

We have to envisage two different moral principles: The egalitarianuniversalistic principle consists in the conviction that every woman and man have the same moral status. The relevant self-understanding becomes manifest in the reciprocal recognition of equal rights for every member of the community. Nazism sets a an entirely different principle. The Germans or the Aryans claim a higher moral status than Non-Germans or Non-Aryans, and follow the self-understanding of a community that gives priority to an order of normative inequality under racial standards.

In additon, there is a network of social norms and institutions tied to a moral principle. The universalistic principle holds essential a civil life free of violence, social and public protection against discrimination of any kind, and a system of law founded on human rights. Contrary to this conception, Nazism aims for the strengthening of the GermanAryan community under the guidance of the "leader" (Fübrer). For Nazism neither domestic nor foreign affairs are limited by the law, and the interests of the people's community are given priority over all other considerations.

Finally, there is a different relation to violence. According to universalistic morality, the state has a monopoly over legitimate violence and all conflicts within a community should be handled with non-violent means. According to Nazi morality, violence is a legitimate means to enforce the homogeneity of the community against its enemies, defined in racial terms. The violent fight for race 
domination in the context of a global struggle is the true human right of a community, which is even above the constitutional law. ${ }^{15}$ By the same token, wars of aggression are declared actions of self-defense. Contrary to this, the universalistic morality imposes an obligation to limit military power and violence to situations of self-defense and to respect the law of the nations.

Such a characterization of the differences between egalitarian universalism and Nazism provides the normative framework for judging the war against Nazism as just. It was just to fight the combination of military aggression, annihilation policy, and moral otherness.

\section{HIROSHIMA: WAR AND MORAL FAILURE}

In light of the normative framework sketched above, the final section of my paper is devoted to an analysis of the disaster of Hiroshima. There's no question that the United States was justified to enter the war after the Japanese attack on Pearl Harbor in 1941 and after the declaration of war on the U.S. by Nazi Germany. There's also no question that the U.S. is a central part of the Western tradition of egalitarian universalism inaugurated by the American and French Revolutions. Japan, on the other side, was dominated by a nationalist-imperialist self-understanding. Japan claimed to be a nation under the auspices of the goddess of sun who inspires the god-like leadership of the Tenno. Contrary to this self-image, however, Japan was judged by Nazi Germany as inferior on racial criteria - yellow, rather than Aryan white - and only accepted as an ally for strategic reasons.

As for Hiroshima, it is indispensable to contextualize the dropping of the atomic weapon within the Potsdam conference that took place from July 17th to August 2nd in 1945. At nearly

15 Adolf Hitler, Mein Kampf, München 1937, 248-251. edition, p. 105. 
the same time, July 16th, the bomb was succesfully tested in New Mexico, and the military order to drop the bomb on Japan was issued on the 25th of July. The Potsdam Proclamation was published the next day, demanding the unconditional surrender of Japan. In addition, we must take notice of the leading figures in the Potsdam conference, namely Winston Churchill, Clement Attlee, Joseph Stalin, and Harry Truman (the successor to the famous Franklin Roosevelt), who took office in April 1945. In retrospect, Albert Einstein speculated that President Roosevelt would never have decided to use the bomb. ${ }^{16}$

Einstein's comment illustrates the crucial point that the political situation was open to a genuine decision. The pros and cons of the decision to drop the atomic bomb on Japan are still debated by historians, political scientists and philosophers to this day. It would, therefore, sound pretentious to give a short answer to all of the problems involved. For our purposes, however, it will suffice to develop a line of argument to support the judgement that the bombing decision was a moral failure.

A preliminary consideration that I would like to offer concerns the background against which the Hiroshima bombing should be considered. By the end of 1944 it was clear that a German nuclear weapon was not going to be built and that it would have been preferable to rethink the strategic option of producing an atomic weapon altogether. The Allied leaders, however, did not seriously discuss any other alternatives.

Of course, this can be seen in the context of an escalating pattern of atrocious practices: the maltreatment and massacre of civilians by the Japanese and the Germans, the mass killing of prisoners of war by the Russians, Japanese and Germans, the practices of area bombing and firebombing by the Anglo-Americans. One telling case in point is the firebombing of Tokyo in March 1945, which killed an estimated

16 The New York Times 19(1946)8, 1. 
100,000 people. This event already demonstrated the impossibility of distinguishing between military and civilian targets. ${ }^{17}$

This background to the war with its moral failings and war crimes emphasizes the challenges involved in the decision to use nuclear weapons. However, the atrocities of the ongoing war could never provide cogent reasons for using the bomb because of its immensive destructive power; not even in revenge for the Pearl Harbor bombing. This points to the moral dimension we have to take into account when judging political leaders and their decisions. The moral question in this case is one of political responsibility under various and serious respects, each of which has moral significance in itself. Details of the decision procedure aside, ultimately we have to take the responsibility of President Truman as decisive for Hiroshima. A hypothetical line of argument can be developed as follows: ${ }^{18}$

4. If Truman had acted according to the 1941 Atlantic Charter, signed by Roosevelt and Churchill, he would have complied with the principle that all peoples have the right to decide their form of government, and

5. If Truman had considered the traditional Japanese self-image that the nation was represented by the god-like Tenno, he would not have demanded the unconditional surrender of

17 Cf. for a broad discussion of the problem of the Allied bombing: A.C. Grayling, Among the Dead Cities. Was the Allied Bombing of Civilians in WW II a Necessity or a Crime?, London 2006.

18 The following is based on several studies discussing the problem of Hiroshima in different ways: G. Alperovitz, Atomic Diplomacy: Hiroshima and Potsdam. The Use of the Atomic Bomb and the American Confrontation with Soviet Power, London/Boulder, Colorado 1985 (revised ed.); T. Hasegawa, Racing the Enemy. Stalin, Truman, and the surrender of Japan, Cambridge/Mass./London 2005; M. Bess, Choices under Fire. Moral Dimensions of World War II, New York 2006; Hiroshima in History and Memory, ed. M.J. Hogan, Cambridge/New York 1996; J.S. Walker, Recent Literature on Truman's Atomic Bomb Decision: A Search for Middle Ground, Diplomatic History 29(2005), 311-334. There are many other sources that could be cited, but for a presentation of the problem in a framework of hypothetical reasoning the aforementioned studies will suffice. 
Japan in the Potsdam Proclamation without an offer of immunity for the Emperor of Japan, and

6. If Truman had taken more seriously the immense task of ending the war and at the same time ensuring a peaceful post-war order in the spirit of the Atlantic Charter, then he would have anticipated the grave consequences of the new atomic weapon, not only for the war against Japan, but also for a new era in global politics, and

7. If Truman had not ignored the expert advice from military staff that the surrender of Japan was only a question of time and that it was not necessary to invade Japan, with the prospect of a number of war casualties comparable to that of the Okinawa battle, and

8. If Truman had not placed so much importance on the Japanese surrender before the Soviet Union was able to enter the war against Japan, and

9. If Truman had taken seriously the warnings in the name of universal humanity from sectors of the military and scientists, he would have demonstrated the bomb on an uninhabited target other than a city...

Taking all these "Ifs" together, it follows that the atomic bombing was a morally wrong decision, a decision to be judged as a war crime.

Some additional comments may clarify this line of argument:

Points (1) to (3) concern the way to deal with the concrete war situation in Japan in light of the progressive framework of the Atlantic Charter and the medium-term perspective for a new postwar order. After the defeat of Nazi Germany, the gobal war scenario had decisively changed. Therefore, time was ripe for considering options for the defeat of Japan more carefully than Truman and his Secretary of State, James Byrnes, seemed able to do. To be sure, a more moderate insistence on the unconditonal surrender of Japan, explicitly securing safe passage to the Tenno, could have meant for the Japanese hardliners a sign of weakness on the part of the Allies. 
However, combined with the threat that the Soviet Union would be in a position to enter the war against Japan by early August 1945, this risk seems acceptable.

Taking this risk would have been consistent with the Atlantic Charter by distinguishing between the disarmament of an aggressive enemy and the specific national identity relative to the Japanese government and the Tenno. This point is further supported by Japanese sources concerning the national creed of the kokutai. The precise meaning of this term is difficult to explain; suffice it to say that its meaning encompasses the strong Japanese tradition of the holy unity of the people and the Emperor. ${ }^{19}$ The Truman administration did have knowledge of the interdependence between Japanese culture and the political system.

Additionally, there can be no doubt that the American government was well-informed about the destructive power of the nuclear weapon and the grave consequences of its unleashing. This is shown, for instance, in a statement by Dwight Eisenhower, the Commander in Chief of the American forces in Europe and later President of the U.S. When Secretary of War Stimson told him that atomic weapons were to be used against Japan, he reacted as follows: "During his recitation of the relevant facts, I had been conscious of a feeling of depression and so I voiced to him my grave misgivings, first on the basis of my belief that Japan was already defeated and that dropping the bomb was completely unnecessary, and secondly because I thought that our country should avoid shocking world opinion. ${ }^{20}$

The statement by Eisenhower leads to points (4) and (5) concerning the concrete circumstances of waging war against Japan. It is a fact

19 Cf. the key source for this: Kokutai No Hongi. Cardinal Principles of the National Entity of Japan, Cambridge/Mass. 1949. How to preseve the kokutai and how to define its meaning became issues of the utmost significance for the Japanese before ending the war with the Tenno's acceptance of the Potsdam Proclamation. Cf. T. Hasegawa, op. cit., chs. 5,6 .

20 Quoted in: G. Alperovitz, op. cit., 14. 
that the Okinawa battle involved heavy losses on the American side, but it is also true that the capture of Okinawa resulted in the dominion of the Pacific war scenario by the Americans. Notwithstanding the willingness of the Japanese war hawks to continue the war in all circumstances, the war situation had changed and this influenced more and more the moderate faction of the Japanese government. To expect a revision of Japanese war politics was no idle hope in the near future and, especially, in respect of the possible entry of the Soviet Union into the Pacific War. By revoking the former Neutrality Pact between Japan and the Soviet Union, the Red Army was able to enter the war in August 1945 and to advance in Manchuria and Kuril Islands. These facts support the thesis that within a rather short time Japan could have been defeated without using the atomic weapon.

Point (6) contains the most explicit instance of moral reasoning to achieve a balance between the concrete war scenario, the destructiveness of the nuclear weapon, and a form of humanism shaped by egalitarian universalism. Even if the demonstration of the bomb on an uninhabited area would have failed to compel a prompt Japanese surrender, it would have shown moral-political responsibility and would have emphasized the moral prestige of America during the final phase of the war, not least in the negotiations with Japan and in limiting Stalin's territorial ambitions in the post-war scenario.

It is worth adding to this point the moral qualms of Leo Szilard as a telling case. In the summer of 1939 he persuaded Einstein to write a letter to Roosevelt in order to warn him about German nuclear capabilities. Later on, as a participant in the "Manhatttan Project" he warned Roosevelt again in April and July 1945. Together with other scientists, this time he tried to convince Roosevelt and Truman to abstain from using the bomb on moral grounds, but his warnings didn't even reach the two presidents. ${ }^{21}$

21 G.J. DeGroot, The Bomb. A Life, Cambridge/Mass. 2005, 21ff., $70 f f$. 
My remarks are meant to expose the challenge of hard decisions at the level of world politics, which involve the need and capacity to reflect on war scenarios both under stable and changing conditions. The Truman government was not able to revise its war aims and weigh the risks under changing conditions of war. The Japanese surrender could have been achieved without the nuclear option and with a more flexible strategy in relation to the Japanese mentality and Tenno system. Therefore, the critique seems justified that the decision to drop the bomb was strongly influenced by the intention to end the war against Japan before the Soviet Union could seriously take action. It is revealing that the order to drop the bomb preceded the published demand for the unconditional surrender of Japan (Potsdam Proclamation) by at least one day. ${ }^{22}$

The risk of Stalin's territorial claims on the Northern part of Japan after the war could not outweigh the serious moral argument that the conscious mass killing of people was not a justifiable option. It may be added that the Japanese government could have agreed to unconditional surrender shortly after the Potsdam Proclamation, thereby unwittingly avoiding the bomb at the last possible moment. This, however, cannot serve as a valid counter-argument. It rather brings us back to point (6) above, which denotes a conscious confrontation of the Japanese with the bomb.

Independently of historical research on the remaining military power of Japan or a precise analysis of the power of the Soviet Union to end the war, there is no utilitarian way out of the problem. The argument that the bomb saved more lives than it destroyed because the war, if continued, would have resulted in a greater number of victims than Hiroshima (and Nagasaki) fails. The reason is that the concrete decision to drop the bomb has to be related to the immediate consequence that thousands of civilians will certainly 
die. To relativize this decision to possible future events that can be assumed only hypothetically comes close to a category mistake.

Therefore, the bombing decision has to be judged in terms of the concrete circumstances in which it was made. An echo of this can be found in the letter of protest sent by the Japanese government to the U.S. through the Swiss legation on August 10,1945. This letter declared the use of the atomic bombs a violation of the Hague Convention prohibiting the use of cruel weapons, and characterised the bombing of Hiroshima and Nagasaki as a crime against humanity. ${ }^{23}$ To be sure, the Japanese government was guilty of its own atrocities and war crimes, but the moral condemnation of the Japanese misdeeds does not excuse those of the U.S.

Looking back at the normative framework above, it is important to distinguish between the crimes of the Holocaust and Hiroshima in the following way:

Notwithstanding the moral critique of the American government, its aim was not to destroy the Japanese people but to end the war by making use of a nuclear weapon. It is therefore a misleading metaphor to speak of a "nuclear holocaust" or allude to a genocidal action in this case. We have to distinguish the bombing of Hiroshima from the crime of the Holocaust. To argue for a different analysis of these two events can also help to dismiss certain general comparisons of Auschwitz and Hiroshima carried out within an overall picture of modernity characterized in terms of a critique of technical rationality. ${ }^{24}$ The Holocaust stands for a rupture of species; Hiroshima does not. ${ }^{25}$

23 T. Hasegawa, op. cit., 199.

24 The topos of such a critique of modernity can be found in autors of quite different philosophical orientations, e.g., Theodor Adorno, Max Horkheimer, Martin Heidegger, Zygmunt Bauman etc.

25 This distinction would be relevant for a critical assesment of the material presented in: R.H. Minear, Atomic Holocaust, Nazi Holocaust: Some Reflection, in: Diplomatic History 19(1995), 347-365. 
In addition, it is important to recognize the personal dimension of hard decisions in history. It goes without saying that the bombing decision was a question of great complexity, which should be judged only after careful consideration. Nevertheless, there remains the peculiar moral level of political responsibility on President Truman. It is such a moral dimension that determines whether a political leader stands the proof of history. Truman did not, or so it seems. ${ }^{26}$

\section{BIBLIOGRAPHY}

Alperovitz G., Atomic Diplomacy: Hiroshima and Potsdam. The Use of the Atomic Bomb and the American Confrontation with Soviet Power, revised ed., Pluto Press, London/Boulder, Colorado 1985.

Arendt H., Eichmann in Jerusalem: A Report on the Banality of Evil, Penguin Books, New York 1994.

Bauer Y., Einige Überlegungen zur Shoah, Zeitschrift für Geschichtswissenschaft 54(2006)6.

Bess M., Choices under Fire. Moral Dimensions of World War II, Knopf, New York 2006.

Bialas W., Moralische Ordnungen des Nationalsozialismus, Vandenhoeck \& Ruprecht, Göttingen 2014.

Clendinnen I., Reading the Holocaust, Cambridge University Press, Cambridge 1999.

DeGroot G.J., The Bomb. A Life, Harvard University Press, Cambridge/Mass. 2005. Fackenheim E.L., To Mend the World. Foundations of Future Jerwish Thought, Schocken, New York 1982.

Friedländer S., Nazi Germany and the Jerws, Vol. I: The Years of Persecution 1933-1939, HarperCollins Publishers, New York 1997.

Friedländer S., Nazi Germany and the Jews, Vol. II: The Years of Extermination, HarperCollins Publishers, New York 2007.

Grayling A.C., Among the Dead Cities. Was the Allied Bombing of Civilians in WWII a Necessity or a Crime?, Bloomsbury, London 2006.

26 This is in agreement with: M. Walzer, Just and Unjust Wars, London 1977: 263-268; J. Rawls, Fifty Years after Hiroshima, in: J. Rawls, Collected Papers, Cambridge/Mass. 1999, 565-572. 
Haas P.J., Morality after Auschwitz. The Radical Challenge of the Nazi Ethic, Fortress Press, Philadelphia 1988.

Hasegawa T., Racing the Enemy. Stalin, Truman, and the surrender of Japan, Harvard University Press, Cambridge/Mass./London 2005.

Hitler A., Mein Kampf, Zentralverlag der NSDAP, München 1937.

Hiroshima in History and Memory, ed. M.J. Hogan, Cambridge University Press, Cambridge/New York 1996.

Kokutai No Hongi. Cardinal Principles of the National Entity of Japan, Harvard University Press, Cambridge/Mass 1949.

Koonz C., The Nazi Conscience, Belknap, Cambridge/MA, London 2003.

Longerich P., Heinrich Himmler: A Life, Oxford University Press, Oxford 2011.

Margalit A., Motzkin G., The Uniqueness of the Holocaust, Philosophy \& Public Affairs 25(1995)1, 65-83.

Minear R. H., Atomic Holocaust, Nazi Holocaust: Some Reflections, Diplomatic History 19(1995), 347-365.

Rawls J., Fifty Years after Hiroshima, in: J. Rawls, Collected Papers, Harvard University Press, Cambridge/Mass. 1999, 565-572.

Rorty R., Contingency, Irony, and Solidarity, Cambridge University Press, Cambridge 1989.

Rorty R., Truth and Progress, Cambridge University Press, Cambridge 1998.

Segel B. W., A Lie and a Libel. The History of the Protocols of the Elders of Zion, ed. by R.S. Levy, University of Nebraska Press, Lincoln 1995.

Snyder T., Bloodlands. Europe between Hitler and Stalin, Basic Books, New York 2010.

The New York Times 8(1946)19.

Tych F., Speech before the German parliament on January, 27, 2010, http://www. bundestag.de/kulturundgeschichte/geschichte/tych/rede/248106.

Walker J.S., Recent Literature on Truman's Atomic Bomb Decision: A Search for Middle Ground, Diplomatic History 29(2005), 311-334.

Walzer M., Just and Unjust Wars, Basic Books, London 1977.

Wegner B., The Waffen-SS. Its Ideology, Organization and Function, Blackwell, Oxford 1990.

Zimmermann R., National Socialism - Bolshevism - Universalism, in: Nazi Ideology and Ethics, eds. W. Bialas, L. Fritze, Cambridge Scholars Publishing, Cambridge 2014, 391-422.

Zimmermann R., Philosophie nach Auschwitz, Rowohlt, Reinbek bei Hamburg 2005. 
Rolf Zimmermann

pohl-zimmermann@t-online.de

University of Konstanz, Department of Philosophy

Universitaetsstrasse 10, 78464 Konstanz

DOI: 10.21697/spch.2017.53.3.07 